\title{
Effect of sand percentage on early-age cracking behaviors of concrete
}

\author{
Fangyu Tang ${ }^{1, a}$, Hengchun Zhang ${ }^{2, b}$, Xixian $\mathrm{Ji}^{3, c}$, Xiaoqiang $\mathrm{Wu}^{4, \mathrm{~d}}$ \\ 1,2,3,4 China State Construction Ready Mixed Concrete Fujian Co. LTD, Fuzhou 350000, China. \\ a13685003632@163.com, b115076527@qq.com, c290634171@qq.com, d59243456@qq.com
}

Key words: concrete; cracking; sand percentage

Abstract: It was analyzed by using flat-type specimens that studied the influence of sand percentage on early-age cracking behaviors. The results showed that concrete early cracking area was decreased first and then increased, while early cracking area was the smallest, as sand ratio of C30 and C50 were separately 44\% and 41\%. The C30 compressive strength was continuously increasing, and compressive strength of C50 first increased and then dropped.

\section{Introduction}

Except corresponding requirements of special positions, the concrete strength and work performance were used as quality index to judge its advantage in the actual application process of concrete, but these indicators didn't consider the volume stability of concrete ${ }^{[1]}$. Poor volume stability led to concrete cracking that formed concrete cracks, which provided channels for harmful substances permeate or migrate from external to internal, accelerated cracking damage process of concrete, decreased concrete durability ${ }^{[2-4]}$.

Sand ratio, refers to the percentage that sand quality accounts for aggregate in concrete. Therefore, sand percentage lead to surface area and porosity of aggregate are both changed, affecting workability and durability of concrete. He Jinyun ${ }^{[5]}$ had studied that sand ratio was the main factor to affect the normal concrete workability, which wasn't a simple linear relationship on concrete. Niu Yinglan ${ }^{[6]}$ and Wei Jiayang ${ }^{[7]}$ had obtained the reasonable sand ratio can make good aggregate gradation, small porosity, positive workability, and easy to stir and mold, form relatively dense concrete, finally improve concrete durability.

The paper studied that crack development regularity under different sand ratio in the maintenance from $3 \mathrm{~h}$ to $24 \mathrm{~h}$ by plate induced cracking, calculated the number of cracks after $24 \mathrm{~h}$, then surveyed crack length and width. Meanwhile combining with mechanical properties to explore the influence and mechanism of sand percentage on early-age cracking behaviors of concrete.

\section{Test conditions}

Raw materials. Cement that selected P.O 42.5 ordinary Portland cement, Tab.1 had shown physical properties. Fly ash that selected II-level fly ash, Tab.2 had shown performance test results. Mineral powder that selected S95 mineral powder, Tab.3 had shown performance test results. Fine aggregate that selected fine river sand and mechanism sand, Tab. 4 had shown performance test results. Coarse aggregate that selected $5 \sim 31.5 \mathrm{~mm}$ continuous-gradation gravel, Tab.5 had shown the performance test results. Admixture that selected polycarboxylate type superplasticizer, solid content was $19.7 \%$, and water-reducing rate was $20.0 \%$. Water that selected running water. 
Tab.1 Basic physical and mechanical properties

\begin{tabular}{|c|c|c|c|c|c|c|c|}
\hline \multirow{2}{*}{$\begin{array}{c}\text { water requirement o } \\
\mathrm{f} \\
\text { normal consistency/ } \\
\%\end{array}$} & \multirow{2}{*}{$\begin{array}{c}\text { surface } \\
\left.\text { area/( } \mathrm{cm}^{2} / \mathrm{g}\right)\end{array}$} & \multicolumn{2}{|c|}{ setting time/min } & \multicolumn{2}{|c|}{$\begin{array}{l}\text { flexural strength/ } \\
\qquad \mathrm{MPa}\end{array}$} & \multicolumn{2}{|c|}{$\begin{array}{l}\text { compressive } \\
\text { strength/MPa }\end{array}$} \\
\hline & & $\begin{array}{l}\text { initial } \\
\text { setting }\end{array}$ & $\begin{array}{c}\text { final } \\
\text { setting }\end{array}$ & $3 d$ & $28 \mathrm{~d}$ & $3 d$ & $28 \mathrm{~d}$ \\
\hline 27.2 & 3480 & 160 & 205 & 6.5 & 8.6 & 30.1 & 49.4 \\
\hline
\end{tabular}

Tab. 2 Test results of fly ash performance

\begin{tabular}{cccccc}
\hline grade & $\begin{array}{c}\text { density } \\
/\left(\mathrm{g} / \mathrm{cm}^{3}\right)\end{array}$ & $\begin{array}{c}\text { fineness }(45 \mu \mathrm{m} \\
\text { sieve residue }) / \%\end{array}$ & $\begin{array}{c}\text { Water demand ratio } \\
/ \%\end{array}$ & $\begin{array}{c}\text { ignition loss } \\
/ \%\end{array}$ & $\begin{array}{c}\mathrm{SO}_{3} \\
/ \%\end{array}$ \\
\hline II-level & 2.7 & 19.2 & 96 & 2.0 & 0.7 \\
\hline
\end{tabular}

Tab.3 Test results of slag performance

\begin{tabular}{ccccc}
\hline grade & $\begin{array}{c}\text { surface area } \\
/\left(\mathrm{cm}^{2} / \mathrm{g}\right)\end{array}$ & $\begin{array}{c}\text { density } \\
/\left(\mathrm{g} / \mathrm{cm}^{3}\right)\end{array}$ & \multicolumn{2}{c}{ activity index $\%$} \\
$7 \mathrm{~d}$ & $28 \mathrm{~d}$ \\
\hline $\mathrm{S} 95$ & 4230 & 2.86 & 82 & 98 \\
\hline
\end{tabular}

Tab.4 Test results of fine aggregate performance

\begin{tabular}{ccc}
\hline fine aggregate & fineness modulus & mud content $/ \%$ \\
\hline mechanism sand & 2.9 & 1.9 \\
fine river sand & 1.8 & 1.2 \\
\hline
\end{tabular}

Tab.5 Test results of coarse aggregate performance

\begin{tabular}{ccccc}
\hline $\begin{array}{c}\text { coarse } \\
\text { aggregate }\end{array}$ & $\begin{array}{c}\text { particle size } \\
/ \mathrm{mm}\end{array}$ & $\begin{array}{c}\text { mud content } \\
/ \%\end{array}$ & $\begin{array}{c}\text { elongated particle content } \\
/ \%\end{array}$ & crush value $/ \%$ \\
\hline gravel & $5 \sim 31.5$ & 0.3 & 3 & 9.0 \\
\hline
\end{tabular}

Proportion of concrete. In order to study the influence of sand percentage on early-age cracking behaviors, Tab.6 had given eight concrete proportion of different sand ratio on C30 and C50.

Tab.6 C30、C50 concrete mix proportion $\left(\mathrm{kg} / \mathrm{m}^{3}\right)$

\begin{tabular}{|c|c|c|c|c|c|c|c|c|c|}
\hline \multirow[b]{2}{*}{$\begin{array}{c}\text { test } \\
\text { number }\end{array}$} & \multirow{2}{*}{$\begin{array}{l}\text { sand } \\
\text { ratio } \\
\% \%\end{array}$} & \multicolumn{3}{|c|}{ cementing materials } & \multicolumn{2}{|c|}{ fine aggregate } & \multirow[b]{2}{*}{ gravel } & \multirow[b]{2}{*}{ water } & \multirow[b]{2}{*}{ admixture } \\
\hline & & cement & $\begin{array}{l}\text { fly } \\
\text { ash }\end{array}$ & $\begin{array}{l}\text { mineral } \\
\text { powder }\end{array}$ & $\begin{array}{c}\text { mechanism } \\
\text { sand }\end{array}$ & $\begin{array}{l}\text { river } \\
\text { sand }\end{array}$ & & & \\
\hline 3001 & 42 & 175 & 105 & 70 & 464 & 309 & 1067 & 170 & 3.8 \\
\hline 3002 & 44 & 175 & 105 & 70 & 486 & 324 & 1030 & 170 & 3.8 \\
\hline 3003 & 46 & 175 & 105 & 70 & 504 & 336 & 1000 & 170 & 3.8 \\
\hline 3004 & 48 & 175 & 105 & 70 & 530 & 353 & 957 & 170 & 3.8 \\
\hline 5001 & 37 & 240 & 96 & 144 & 391 & 260 & 1109 & 160 & 5.4 \\
\hline 5002 & 39 & 240 & 96 & 144 & 412 & 274 & 1074 & 160 & 5.4 \\
\hline 5003 & 41 & 240 & 96 & 144 & 432 & 288 & 1040 & 160 & 5.4 \\
\hline 5004 & 43 & 240 & 96 & 144 & 454 & 303 & 1003 & 160 & 5.4 \\
\hline
\end{tabular}


Test methods. The method for measuring concrete early-age cracking resistance referred to GB/T 50082-2009, testing early-age cracking resistance of concrete under constraints. The experiments used flat thin plate specimens with seven crack inducers, the size of plate was $800 \mathrm{~mm}$ x $600 \mathrm{~mm} \mathrm{x}$ $100 \mathrm{~mm}$. Putting briquettes in curing room on $(20 \pm 2){ }^{\circ} \mathrm{C}$ and humidity on $(60 \pm 5) \%$ after being compacted and smoothed, then adjusting the fan speed to keep wind speed on the surface center reach $(5 \pm 0.5) \mathrm{m} / \mathrm{s}$ until specimens had shaped 30mins. In the process of experiments, some cracks must be recorded when specimens had respectively molded $3 \mathrm{~h}, 4 \mathrm{~h}, 5 \mathrm{~h}, 6 \mathrm{~h}, 8 \mathrm{~h}, 24 \mathrm{~h}$. At last, using $80 \mathrm{X}$ reading microscope to measure the crack width along the direction of crack inducers. The mechanical properties of concrete refers to GB/T 50081-2002, measuring $7 \mathrm{~d}$ and $28 \mathrm{~d}$ compressive strength of concrete standard specimens.

In the paper, evaluation indexes of slab cracking were carried out to according to "Concrete structure durability design and construction guide" which had been proposed by the Civil Engineering Society of China, formulas were shown as follows. In the formulas, $\mathrm{W}_{\mathrm{i}}$ was the maximum width of crack I (mm), $\mathrm{L}_{\mathrm{i}}$ was the length of crack I (mm), N was total number of cracks (root), S was $0.36 \mathrm{~m}^{2}$.

Average cracking area of cracks:

$$
\mathrm{A}=\frac{1}{2 N} \sum_{i}^{N} W i \cdot L_{i}\left(\mathrm{~mm}^{2} / \mathrm{root}\right)
$$

Number of cracks per unit area:

$$
\mathrm{B}=\frac{N}{s}\left(\mathrm{root} / \mathrm{m}^{2}\right)
$$

Total cracking area per unit area: $\mathrm{C}=\mathrm{A} \cdot \mathrm{B}$.

\section{Test results and analysis}

The experiment of concrete cracking behaviors. The experiment studied the influence of sand percentage on early-age cracking behaviors by plate induced cracking. The paper comprehensively evaluated cracking resistance of concrete on measuring cracks length along the direction of crack inducers, reading cracks width, calculating total cracking area.

Development trend of early-age cracks in concrete. It was observed that concrete surface cracks with the same strength grade were in the same trend. Putting briquettes at $(20 \pm 2)^{\circ} \mathrm{C}$ and humidity on $(60 \pm 5) \%$ that would find no cracks on concrete surface between forming $3 \mathrm{~h}$ and $6 \mathrm{~h}, \mathrm{C} 30$ surface along the direction of crack inducers after $8 \mathrm{~h}$ that began to appear subtle cracks, but C50 specimens had subtle cracks between $6 \mathrm{~h}$ and $8 \mathrm{~h}$. With the extension of time, apparent cracks could be seen after 24h, then respectively testing surface cracks of C30 and C50 specimens, results were shown in Fig. 1 and Fig. 2 that the width of $\mathrm{C} 30$ surface cracks were in the range from $0.05 \mathrm{~mm}$ to $0.50 \mathrm{~mm}$, and the width of C50 surface cracks were between $0.15 \mathrm{~mm}$ and $0.38 \mathrm{~mm}$.

Analysis and performances of concrete cracking Tab. 7 had given concrete cracks with different numbers. From the results of $\mathrm{C} 30$ and C50 early-age cracking can be seen that the total cracking area per unit area decreased with sand ratio increasing in a certain range, but the fracture area increased with sand ratio increasing when sand ratio exceeded a certain critical value. 

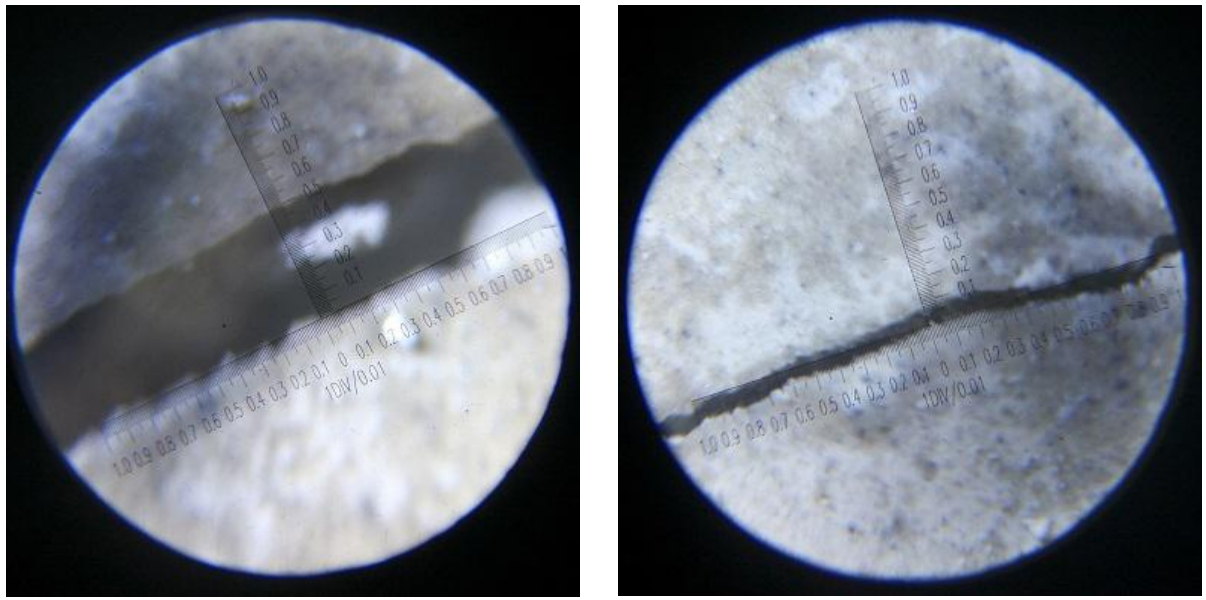

Fig.1 Crack micrograph of curing NO.3002 concrete after 24h
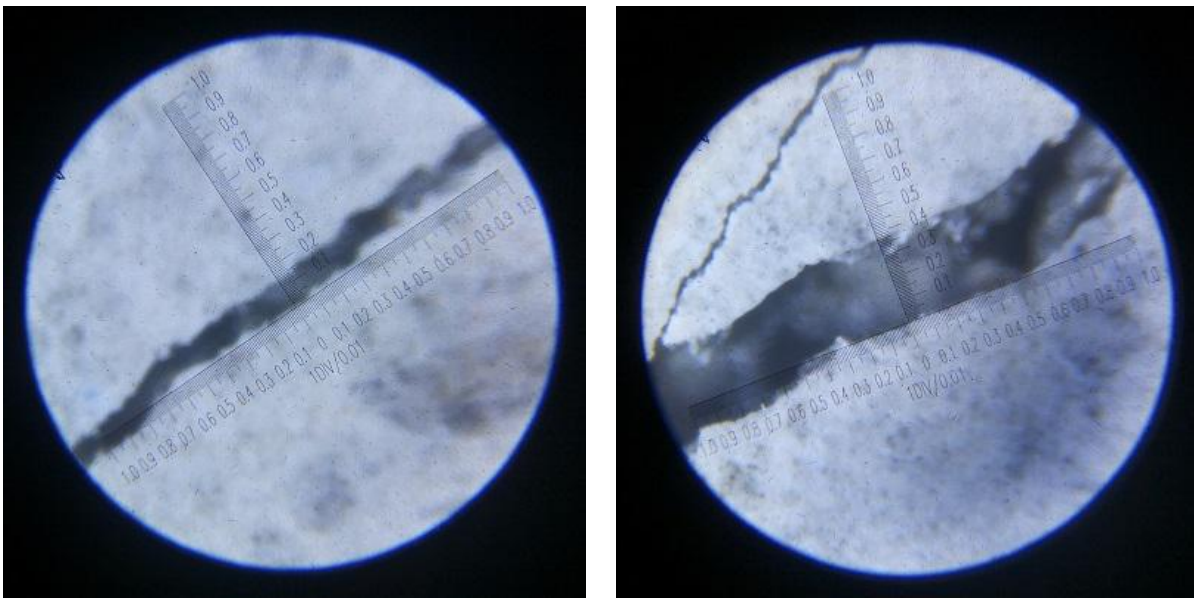

Fig.2 Crack micrograph of curing NO.5003 concrete after 24h Tab.7 Concrete cracking cases of different grade

\begin{tabular}{cccc}
\hline $\begin{array}{c}\text { test } \\
\text { numbers }\end{array}$ & $\begin{array}{c}\text { Average cracking } \\
\text { area of cracks } \\
\left(\mathrm{mm}^{2} / \text { root }\right)\end{array}$ & $\begin{array}{c}\text { Number of cracks per } \\
\text { unit area } \\
\left(\text { root } / \mathrm{m}^{2}\right)\end{array}$ & $\begin{array}{c}\text { Total cracking area } \\
\text { per unit area } \\
\left(\mathrm{mm}^{2} / \mathrm{m}^{2}\right)\end{array}$ \\
\hline 3001 & 32 & 6.3 & 201.6 \\
3002 & 85 & 2.1 & 178.5 \\
3003 & 34 & 8.3 & 282.2 \\
3004 & 76 & 4.2 & 319.2 \\
5001 & 37 & 6.3 & 233.1 \\
5002 & 27 & 4.2 & 113.4 \\
5003 & 3 & 2.1 & 6.3 \\
5004 & 18 & 4.2 & 75.6 \\
\hline
\end{tabular}

When sand ratio was small as the total amount of aggregates was kept constant, coarse aggregates in concrete was too much, and the amount of cement mortar was relatively small, which let mortar insufficiently coat the surface of coarse aggregates. All those aspects that reduced concrete density, accelerated the moisture in concrete along the capillary migration rate to outside, dropped the ability of concrete to resist deformation, led to a larger area of early-age cracking.

As sand rate increasing and gradually approaching the critical value, the amount of fine aggregates was increased and the amount of mortar was enough to coat the surface of coarse aggregates that improved concrete density, enhanced resistant capability, and decreased early-age 
cracks area. Total surface areas of aggregates could be increased when sand rate was larger than the critical value. Thanks to the strength of cement mortar was less than aggregates, elastic modulus and thermal expansion coefficients were different, existing radial stress on interface between cement pastes and aggregates had a negative effect on concrete early-age cracking resistance. The volume stability of concrete can be reduced with the proportion of coarse aggregate decreasing, resulting in dropping concrete cracking resistance. These factors led to concrete early-age cracking area increase.

Results and analysis of concrete mechanical properties. Fig.3 and Fig.4 respectively showed the $7 \mathrm{~d}$ and $28 \mathrm{~d}$ compressive strength of C30, C50. From concrete compressive strength trends of number 3001 to 3004 and number 5001 to 5003 can be seen that compressive strength gradually increased, while sand ratio increasing within a certain range. However, concrete compressive strength was decreased by number 5003 and 5004 specimens.

Maintaining a stable amount of cementing material in concrete molding process, the amount of mortar couldn't completely wrap the surface of coarse aggregate and the gap between aggregates when sand ratio was small. With the increasing of sand ratio, concrete encapsulation and workability were obviously improved, and the compactness was also enhanced, which made compressive strength increase. But sand rate was much larger than the normal value that can be increased aggregate surface areas and porosity, thinned the aggregate thickness of aggregate layer, weaken the internal bonding capacity of concrete. In addition, high sand ratio may be caused poor performance of concrete, difficult to form the ideal structure with embedded lock-type, decreasing the density of hardened concrete, finally reducing concrete strength. At the same time, higher sand ratio destroyed the mechanical cohesion between coarse aggregates, which was one of the main reasons for decreasing of concrete strength ${ }^{[8]}$.

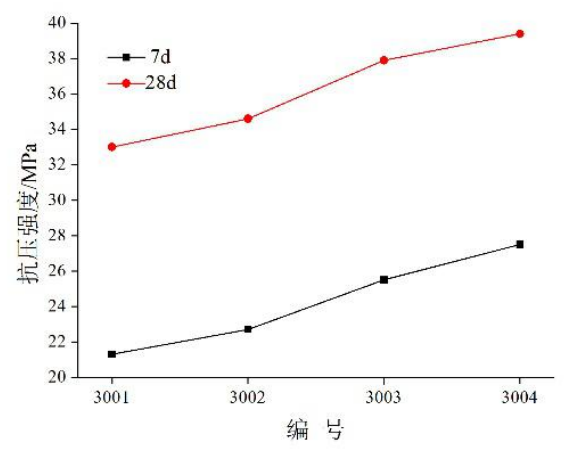

Fig. 3 The compressive strength of C30 concrete

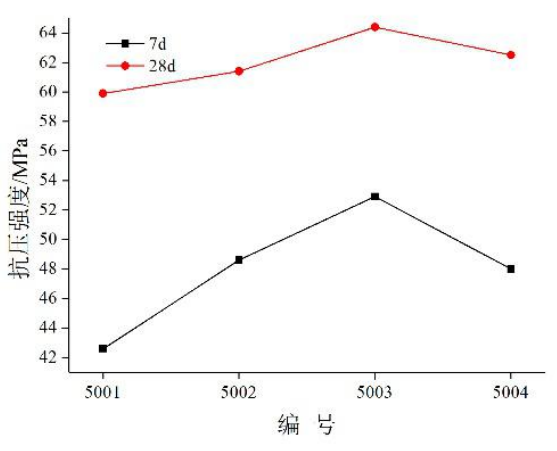

Fig.4 The compressive strength of C50 concrete

\section{Conclusions}

1) Putting briquettes at $(20 \pm 2)^{\circ} \mathrm{C}$ and humidity on $(60 \pm 5) \%$ that would find $\mathrm{C} 30$ specimens surface along the direction of crack inducers after forming $8 \mathrm{~h}$ that began to appear subtle cracks, but C50 specimens had subtle cracks between $6 \mathrm{~h}$ and $8 \mathrm{~h}$. With the extension of time, apparent cracks can be seen after $24 \mathrm{~h}$.

2 ) As sand ratio of concrete was in a certain critical value, the crack area was the biggest after curing $24 \mathrm{~h}$ at $(20 \pm 2)^{\circ} \mathrm{C}$ and humidity on $(60 \pm 5) \%$.

3) With sand ratio growing, C30 compressive strength was continuously increasing, and the compressive strength of C50 first increased and then dropped. 


\section{References}

[1] Baoguo Ma, Xingang Wang, Wenquan Liang, et al. Study on Early-age Cracking of Cement Mortar with High Range Water Reducing Admixtures[J]. Journal of Building Materials, 2006, 8(6): 593-598(In Chinese).

[2] Jianfu Wang, Quanbin Yang, Effect of slag on the resistance to cracking of concrete at early age[J]. China Concrete and Cement Products, 2006 (1): 10-13(In Chinese).

[3] Ping Zhang, Kun Wang, Qiuyi Li, et al. Experimental research on the early cracking resistance of concrete with high- volume mineral admixture[J]. Concrete, 2012 (1): 71-73(In Chinese).

[4] Li Li , Wei Sun, Zhiyong Liu. A slab test of early-age plastic shrinkage and cracking of high performance concrete[J]. Concrete, 2004 (12): 33-36(In Chinese).

[5] Jinyun He, Ruijing Li, Jizong Wang. The study of the influence of sand percentage on the workability and strength of concrete[J]. Journal of Hebei Institute of Architectural Science and Technology, 2002, 19(4): 27-29(In Chinese).

[6] Yinglan Niu. Sand ratio on the properties of concrete are mainly impact analysis[J]. China Building Materials Science and Technology, 2014 (2): 12-13(In Chinese).

[7] Jiayang Wei, Zhenghong Tu, Jingjian Li, et al. Methods for selecting reasonable sand ratio of concrete[J]. Guangdong Building Materials, 2014, 30(4): 10-13(In Chinese).

[8] Gutierrez P A, Cánovas M F. High-performance concrete: requirements for constituent materials and mix proportioning[J]. Materials Journal, 1996, 93(3): 233-241. 